\title{
The Politics of Same-Sex Marriage: Tracing THE ISSUE Through Congress AND THE Courts
}

\author{
By Caleb Andrew Temple
}

Abstract: The issue of same-sex marriage is currently a topic of fierce debate in this country. To help policymakers, practitioners, and members of the American public better understand both the topic and the direction of the debate, this article gives a brief history of the issue, describes some significant legislative and legal developments, and offers some comments on the ways in which the outcome of this debate could potentially affect federal policy.

In recent years, the country's delicate commitment to egalitarianism and civil liberties has been tested by one of the most divisive issues of the day: same-sex martiage, defined as a legal marriage between two people of the same sex. Due to the intense emotions involved, it is not surprising that the issue of samesex marriage has become a pivotal factor in U.S. politics.

The issue of same-sex marriage is now in legislatures (including the U.S. Congress) and courthouses across the country and may one day be heard by the Supreme Court. In order to help policymakers, practitioners, and members of the American public understand the issue and the direction of this debate, this article recounts the recent history of the topic, describes significant events over the past decade (including events that are currently unfolding both in the U.S. and abroad) and offers an overview of some of the possible effects that legalization of same-sex marriage could have on federal policy.

\section{The Door is Opened}

In its May 1993 ruling in the case Baebr et al. v. Lewnin (74 Haw. 530), the Supreme Court of Hawaii

Andrew Temple is currently a candidate for the Master of Public Administration degree at The George Washington University. He will graduate in May 2006 with a specialization in public-private policy and management. A native of Houston, Texas, he earned a bachelor's degree magna cum laude at Southern Methodist University. reversed a trial court's decision involving three samesex couples who had filed suit against the state after being prohibited from obtaining marriage licenses on the grounds that the partners to each marriage were of the same sex. The plaintiffs claimed that the state marriage statutes violated their rights to privacy and equal protection granted by the state constitution. The Hawaii Supreme Court found that because of the state constitution's Equal Rights Amendment, laws prohibiting same-sex marriage licenses were potentially unconstitutional under the ERA's equal protection clause, which has been interpreted to include sex as a "suspect category." As such, a statute that discriminates on the basis of sex is subject to a "strict scrutiny" analysis which assumes that the statute is unconstitutional unless the state can show a compelling state interest which justifies the discrimination (Baebr et al. v. Lewin, 571 - 581):

The new trial began in September 1996. Three months later, Judge Kevin S.C. Chang ruled that the state had not met its burden of proof by demonstrating that the existing marriage statutes reflected a compelling state interest and were therefore unconstitutional. The court enjoined the Director of the Department of Health from denying any application for marriage on the sole grounds that the applicants were of the same sex (Baehr et al. " Miike, Civ. No. 91-1394 Haw. Cir. Ct.1996).

The results of the Baebr case fueled nationwide speculation that Article IV, Section I of the U.S. Constitution, known as the "Full Faith and Credit" clause, would force states to recognize as valid samesex marriages performed in other states. The only 
exception would be for "marriages deemed contrary to the [state's] strong public policy," as the Congressional Research Service notes in a report on the issue (CRS 2004). ${ }^{1}$ The decision in the new trial was appealed even before the Hawaii Supreme Court acted on the appeal, state legislatures around the country had already taken action to protect their states from having to recognize same-sex marriage. As of July 1,1996 , fourteen states ${ }^{2}$ had enacted laws designed to protect their own marriage statutes, a trend which attracted the attention of both houses of Congress (U.S. House 1996a).

\section{The Defense of Marriage Act of 1996 (DOMA)}

The $104^{\text {th }}$ Congress entered the arena by passing The Defense of Marriage Act (DOMA). Ostensibly, the bill was proposed to accomplish two primary purposes: 1) "to defend the institution of traditional heterosexual marriage," and 2) to "protect the right of the States to formulate their own public policy regarding the legal recognition of same-sex unions, free from any federal constitutional implications that might attend the recognition by one State of the right for homosexual couples to acquire marriage licenses" (U.S. House 1996a). From the debate and subsequent reports regarding the bill, however, it was clear that in proposing DOMA many in Congress intended the bill to meet broader goals. In the House Committee on the Judiciary's recommendation to the full House, for instance, the committee listed two additional governmental interests that would be served by the bill: it would "defend traditional notions of morality" and it would help to "preserve scarce government resources" (ibid). While Congress cited the economic argument as a central part of the rationale behind DOMA, evidence suggests that the law reflected, instead, a desire to maintain traditional values.

The Defense of Marriage Act was designed to define marriage at the federal level so that the states, by extension, would be able to pass their own laws regarding the legality of same-sex marriage and would not be forced to recognize marriages from other states pursuant to the Full Faith and Credit clause. Opponents of DOMA labeled it an outright attack on homosexuals or same-sex couples in general (Kennedy 1996); others called it a "response to an attack upon the institution of marriage" (Lott 1996).

DOMA attempted to accomplish its outlined purposes by amending the U.S. Code in two places. First, the bill altered Chapter 115 of Title 28 to include a clause stating that no state, territory, Indian tribe, or possession of the U.S. is required to recognize a relationship between two same-sex individuals as a marriage even though it might be treated as such in another state nor does any state have to recognize any rights or benefits arising from such a relationship that may have been recognized in the granting state (U.S. House 1996b). Second, DOMA amended Chapter 1 of Title 1 to define for federal purposes "marriage" as "a legal union between one man and one woman as husband and wife;" "spouse" would refer "only to a person of the opposite sex who is a husband or wife" (ibid).

\section{Framing the Debate: The Role of Federalism In DOMA}

The Congressional debate around DOMA's passage in 1996 set off a nationwide discussion on the issue of same-sex marriage. Individuals and interest groups represented a variety of perspectives, some viewing the issue through purely moral or religious lenses while others took a strong stand on federalism and state's rights and still others expressed concern about civil liberties and equal protection under the law. Proponents of DOMA argued that the law supported a state's right to decide-free from outside interference-its own policy on matters such as samesex marriage. Opponents claimed that homophobia was the real reason for the law. Interestingly, the issue of federalism was also used by DOMA's opponents to argue vigorously against the bill's passage.

Proponents of DOMA felt that "activist" judges were creating policy from the bench counter to the wishes of the people. They saw the bill as a necessary move to ensure that the effect of the Baebr decision stayed in Hawaii instead of becoming a vehicle for national approval of same-sex marriage. In its report to the House, the Judiciary Committee argued that "by taking the Full Faith and Credit Clause out of the legal 
equation surrounding the Hawaii situation, Congress will to that extent protect the ability of the elected officials in each State to deliberate on this important policy issue free from the threat of federal constitutional compulsion" (U.S. House 1996a). Proponents of DOMA argued that forcing one state to accept another state's definition of marriage violated the core principles of federalism which seek to protect states' rights. By clarifying exactly when a state was not required to give full faith and credit to another state's laws or proceedings, advocates saw DOMA as protecting traditional federalism by ensuring the right of states to decide the issue for themselves (Tom 1996; Wardle 1996).

Opponents of DOMA also used the federalism issue to support their point, atguing that the very involvement of the federal government in deciding this issue encroached on states' rights. The proposed bill, according to its critics, brought the federal government into an area where Congress did not have the tight to legislate. Furthermore, by providing states with authorized reasons for refusing to recognize another state's decisions, Congress was overstepping its constitutional boundaries for passing legislation pursuant to the Full Faith and Credit clause (Birch 1996; Saperstein 1996).

This argument centered on the notion that the Full Faith and Credit clause was originally designed to ensure uniformity among the different states, thereby creating a more cohesive nation. When Congress has legislated according to the Full Faith and Credit clause in the past, the purpose has been to extend rights to individuals previously denied them but never to provide the states an opportunity to deny rights protected by other states (CRS 1996). University of Chicago law professor Cass R. Sunstein enunciated this very point in his testimony before the Senate Judiciary Committee, stating that the Full Faith and Credit Clause was designed to foster a system of cooperation among the states, not an environment of competition where "judgments could be made part of interstate rivalry" (Sunstein 1996). With DOMA, critics claimed that Congress acted to decrease the Full Faith and Credit clause obligation, not to ensure uniformity of rights (CRS 1996).

Opponents of DOMA also argued that the bill was largely unnecessary because other safeguards, including the public policy exemption, already existed to protect state autonomy. Further, as the dissenters on the House Judiciary Committee argued, there was no "emergency" that required the immediate resolution of the same-sex marriage issue in the U.S. Congress, as the Hawaii case would probably not be decided for years due to the expected appeals. Some opponents of DOMA went even further, asserting that support of the bill was based purely on anti-gay sentiment.

A leading opponent of the bill, Senator Ted Kennedy (D-MA), chose to refer to DOMA as the "Defense of Intolerance Act" (Kennedy 1996). In hearings on the proposed bill, Sen. Kennedy articulated his view of its redundancy, arguing that it could not possibly give the states any more rights than they already possessed to reject the laws and decisions of any another state. In his opinion, the bill was not only a waste of time but also an election-year political maneuver meant only to divide the country (ibid).

In the end, voices like Senator Kennedy's were unsuccessful. Despite the emotional arguments against the bill, the Defense of Marriage Act passed the Congress with a significant majority. While there was some question about whether federalism, as opposed to simply anti-gay sentiments, was really the driving force behind the law, on the whole a majority of those in Congress did not view the bill as an example of Congress overstepping its authority under the Constitution.

\section{Policy Implications of DOMA}

Before turning to a discussion of the state-level responses to DOMA, it is useful to consider some of the major policy implications of the legislation both at the federal and state level, many of which will affect all states in the nation. DOMA's far-reaching policy implications at the federal level for same-sex couples wishing to marry in the U.S. include the denial of a wide range of federal benefits to same-sex couples whose eligibility requirements rely on marital status. From spousal benefits under the Social Security program and tax breaks for married couples to healthcare and visitation benefits and rights, the U.S. Government Accountability Office (GAO) found that marital status affects eligibility for more than 1,100 federal statutory provisions in the US. Code (U.S. GAO 2004). As the findings in the GAO's recent report 
entitled "Defense of Marriage Act: Update to Prior Report" demonstrate, the denial of marriage to same-sex couples has the potential to reach into nearly every aspect of federal activity and confer significant hardships on same-sex couples. In fact, a report released by the Human Rights Campaign estimates that the damage done to surviving partners-as opposed to surviving spouses-can run in excess of tens of thousands of dollars (Bennett and Gates 2004).

Consider, for example, the issue of Social Security as it applies to gay, lesbian and bisexual seniors. When one spouse in a traditional marriage dies, the surviving spouse receives Social Security survivor benefits from the federal government. But same-sex couples are not recognized as legally married by the federal government so they are not eligible for such benefits.

Some of the largest discrepancies between what married people and same-sex couples are allowed can be found in the tax code. When one spouse leaves his/ her retirement accounts ( $401 \mathrm{~K}$ or IRA) to the other, the surviving spouse inherits the funds tax-free whereas same-sex partners in a long-term relationship are heavily taxed on such assets. Furthermore, same-sex partners are charged an estate tax on the inheritance of a home, even if jointly owned, while married spouses are exempt from this levy (ibid). Same-sex couples, particularly wealthy ones, are further discriminated against by being denied the ability to make unlimited inter-spousal gifts. With the marital deduction effectively excluded, same-sex couples are limited to per-donee annual exclusions (currently $\$ 11,000)$ and lifetime unified gift-tax exemptions (currently $\$ 1$ million) (Medwed 2004). Furthermore, without recognition of a legal marriage, same-sex couples do not have the opportunity to explore tax filing options (such as filing jointly or singly) and subsequently decide which is more advantageous to them.

The policy implications of legalizing same-sex marriage transcend the U.S. tax code, reaching some of the core issues associated with the American family. One commonly cited reason for extending the benefits of traditional marriage to same-sex couples is the matter of healthcare, specifically coverage for spouses. While a small minority of businesses in the private sector offers healthcare benefits to the same-sex partners of their employees, on the whole the business world takes its cues from the federal government in only offering coverage to the spouses of workers. $\Lambda$ s a result, an emplovee's same-sex partner is forced to buy his or her own policy. Further, workers who do receive some coverage for their same-sex partner are required to pay federal income tax on the value of the insurance provided (Human Rights Campaign 2004). As healtheare costs continually rise, it is no surprise that this issue is often cited by supporters of same-sex marriage.

Related to the subject of healthcare is the issue of hospiral visitation rights. Legally married couples are guaranteed the right of visitation when a spouse is hospitalized and spouses can make certain medical decisions for each other. Same-sex couples are not guaranteed these rights and are often refused the opportunity to see their partners in the hospital. Furthermore, since same-sex couples are not legally recognized as responsible for each other, they do not automatically have the right to make medical decisions for each other (ibid).

Another issue is the question of adoption by samesex couples. The laws regarding gay adoption vary by state, further complicating the situation. While some states allow same-sex couples to adopt, others explicitly prohibit it. Adding to the complexity, some states even refuse to recognize adoptions by same-sex couples from other states. Currently, the courts in 22 states $^{3}$ and the District of Columbia have permitted gay, lesbian, and same-sex couples to adopt (Human Rights Campaign Web Site 2004). Conversely, among those less permissive states Florida, Utah, and Mississippi explicitly tefuse to recognize these individuals as legal couples and as such prohibit them from adopting as a couple (ibid).

The difficulties and confusion regarding adoption in the U.S. by gay and lesbian couples have led some to adopt children from overseas. Even this option can hit a roadblock, however, as same-sex couples marking the "married" box on the application risk the chance of having their applications rejected for misrepresenting their legal status in the U.S. In light of these complications and the fact that no conclusive research has been conducted regarding the impact on children of being raised by same-sex couples, the issue of same-sex adoption will remain at the forefront of the same-sex marriage debate (Ordonez, The Boston. Gilobe, May 8, 2004). 


\section{State Actions on Same-Sex Marriage After DOMA}

In light of the numerous policy implications of legalizing same-sex marriage and the realization that through DOMA, the federal government had given the states license not only to make their own decisions on the issue but to reject the decisions made by other states, state (and local) governments dealt with the issue in different ways. On April 29, 1997, partly in response to the lower court's 1996 decision enjoining the state from denying marriage licenses solely on the grounds that a couple was of the same sex, the Hawaii legislature passed a proposed amendment to the state's constitution that granted the legislature the power to reserve marriage to opposite-sex couples. The amendment was later ratified by the electorate in November 1998 (Baebr et al. v Miike, 1999 Haw. LEXIS 391, 5 1999). A year later, the Hawaii Supreme Court reversed the trial court's 1996 decision and remanded the case for entry of judgment in favor of the state, citing the new constitutional amendment which placed the state marriage statutes on "new footing" (Baebr et al. v Miike, 6-8).

\section{Massachusetts' Contribution}

\section{to the Debate}

Not all states raced to deny gay couples the opportunity to marry following DOMA's passage and the Hawaii Supreme Court's 1999 decision. In 2003, Massachusetts' highest court effectively legalized samesex martiage in that state. In Goodridge $\nu$. Department of Public Health, (440 Mass. 309 [2003]), the Supteme Judicial Court held that denying same-sex couples the right to marry was a violation of the state's constitution. With this ruling, Massachusetts became the first and only state to officially and legally issue marriage licenses to same-sex couples. The court's decision was appealed to the federal courts on a variety of constitutional questions; meanwhile, opponents of gay marriage began to push for an amendment to the US Constitution explicitly defining marriage as an arrangement of one woman and one man.
On November 29, 2004, the U.S. Supreme Court refused to hear an appeal from the Supreme Judicial Court's decision. As Richard Willing noted in a USA Today article on November 30, 2004, the Court's rationale was that it would not decide a case involving a state court's interpretation of the state's constitution, a traditional reason for the Court to reject an appeal.

While the Supreme Court was letting the Massachusetts court decision stand, DOMA was undergoing its own legal challenges. As recently as January 2005, DOMA was upheld as constitutional in a legal challenge brought in Florida. A District Court judge ruled against a same-sex couple from Florida who was married in Massachusetts and claimed that DOMA violated their constitutional rights by denying the couple equal protection as well as the benefits of the Full Faith and Credit Clause (Wilson v. Ake, U.S. Dist. Lexis 755 2005). In the ruling, the judge noted that adopting the plaintiffs" "rigid and literal interpretation of the Full Faith and Credit [Clause] would create a license for a single State to create national policy" (Wilson v. Ake, 7-10).

\section{California Joins the Conversation}

In the state's 2000 primary elections, Californians approved Proposition 22 which effectively defined marriage as exclusively between a man and woman. However, on February 10, 2004, San Francisco Mayor Gavin Newsom chose to ignore the state-imposed restrictions on same-sex marriage and otdered the county clerk to begin issuing "gender neutral" martiage licenses to same-sex couples (Lockyer v. City and County) of San Francisco, 33 Cal. 4th 1055 2004). In response, thousands of gay and lesbian couples descended on the courthouse in the following weeks. The liberal interpretation of the law was relatively short-lived, though, as the state's highest court ruled unanimously on August 12, 2004, that the city had acted beyond its legal authority in issuing the licenses. In the same ruling the court nullified in a 5-2 vote the more than 4,000 marriage licenses that had been issued (Lockyer $\mathrm{v}$. City and County of San Francisco, 1121). Then on March 14, 2005, a San Francisco Superior Court judge ruled that the state's ban on same-sex marriage was indeed unconstitutional (Coordination Proceeding 2005). If the Superior Court's decision is upheld by the state's 
highest court, California would become only the second state to offer the rights and privileges of legal marriage to same-sex couples.

While it appears that the state has not suffered any real economic damage from the legal battles, the incidents have sparked widespread concern about the potential for legal chaos. Proponents of an amendment to the U.S. Constitution cite the situation in California as evidence that a federal standard is desirable if for no other reason than simply to maintain order.

\section{Other State Actions}

Currently, 43 states bat the recognition of samesex marriages by the state either through constitutional provisions or current marriage laws (Human Rights Campaign 2005a). Of these 43 states, as of March 30, 2005 , fourteen states ${ }^{4}$ had constitutional amendments, in addition to their current laws, awaiting approval by the voters (ibid). In addition, during the November 2004 general election, eleven states ${ }^{5}$ successfully passed ballot initiatives to create state constitutional amendments to ban same-sex marriage (Cooperman, The Wasbington Post, November 4, 2004). If the fourteen states currently seeking amendments are successful, 25 states in all will have amended their constitutions to forbid same-sex couples from marrying.

By contrast, seven states ${ }^{6}$ and the District of Columbia either do not explicitly address the issue or do not refuse to recognize same-sex marriages celebrated in another jurisdiction (Human Rights Campaign 2005b). While Massachusetts is still the only state to officially issue marriage licenses to same-sex couples, states such as New York have taken a slightly less controversial stance by requiring the recognition of same-sex marriages celebrated in another jurisdiction. Still other states, such as New Jersey, have taken the route of domestic partnership laws to ensure same-sex couples receive some limited tights.

\section{Further Developments IN THE}

\section{U.S. AND ABROAD}

While states are using their authority under DOMA to address the issue of same-sex marriage as they see fit, there is some support for further, more decisive federal action. Specifically, some in Congress have raised the issue of amending the U.S. Constitution to define marriage in a traditional way. On May 21, 2003, Representative Marilyn N. Musgrave (R-CO) introduced a proposed constitutional amendment, H. J. RES. 56, to define marriage as solely between a man and a woman (Library of Congress 2003a). Senator A. Wayne Allard (R-CO) introduced a companion bill, S. J. RES. 26, on November 25, 2003 (Library of Congress 2003b). The House and Senate resolutions, both known as the Federal Marriage Amendment of 2003, state that marriage in the U.S. should "consist only of a union of a man and woman" and that, furthermore, no state constitution could be "construed to require that marital status or the legal incidents thereof be conferred upon unmarried couples or groups" (ibid). Despite an aggressive push from conservatives for passage, however, the Federal Marriage Amendment of 2003 died in committee in both houses.

While the issue of same-sex marriage is being debated and litigated in the state and federal legislative and judicial systems of the United States, it is simultaneously being addressed in other countries. On February 1, 2005, Justice Minister Irwin Cotler introduced legislation in the Canadian Parliament that would allow same-sex couples to marry legally in Canada while still providing the religious members of society the right to refuse to perform the ceremonies (House of Commons of Canada 2004). At the time of publication, the proposed bill is expected to pass, though only by a slim margin. The Civil Marriage Act (Bill C-38) is the most recent attempt in that country to extend the right of civil martiage to its gay, lesbian, and bisexual populations.

Unlike in the U.S., however, the proposed measure has been met with higher levels of public support in the country. The bill was expected to pass thanks in part to a December decision by the Supreme Court of Canada stating that the federal government could change the definition of marriage, giving same-sex couples the right to marry. The Court observed that the government had failed to appeal a number of lower court decisions which ruled that refusing same-sex couples the right to marry was discriminatory; therefore, the Court concluded, the federal government had, sub silentio, accepted that position as its own 
(Reference re Same-Sex Marriage 2004). Should Canada change its position on same-sex marriage, as it appears poised to do, the decision would surely put pressure on the U.S. to reconsider the issue in a positive light.

\section{Alternative Approaches}

The strong opposition to expanding the definition of marriage to include same-sex couples in the U.S., along with the complicated policy issues that would follow such legalization have led many people to propose alternative approaches. One of the most commonly recommended strategies, both within the U.S. and internationally, for ensuring benefits for samesex couples is a system of civil unions or domestic partnerships.

The terms "civil unions" and "domestic partnerships," though often used interchangeably, have slightly different meanings. Civil union is a new legal category created specifically with same-sex couples in mind. Civil unions, for the most part, attempt to address the benefit discrepancies between married and samesex couples by providing state-level spousal tights to those in same-sex relationships. Domestic partnerships, much like civil unions, seek to offer benefits to all unmarried couples, regardless of sexual preference.

At the time of publication, Vermont is the only state that offers civil union status to its citizens, though other states are on the verge of legalizing civil unions. The Connecticut House passed a measure on April 13,2005 , that would allow civil unions in the state and it is reported that the Governor will sign the bill if it passes the Senate (Yardley, The New York Times, April 14, 2005). On the same day Oregon's Governor requested that the legislature introduce a bill that would legalize civil unions in that state Jepsen, The Mail Tribune, April 14, 2005). Currently, California and New Jersey have domestic partnership laws, and Connecticut, Hawaii, Maine, and D.C. also have some type of law conferring certain spousal benefits to same-sex partners, though not always called domestic partnership laws (Hartman 2004).

Many same-sex marriage advocates do not view civil unions or domestic partnership laws as going far enough towards providing true equality. Instead, many believe these alternatives further relegate same-sex couples to second-class-citizen status. ${ }^{7}$ While civil unions and domestic partnerships are clearly considered by many to be unsatisfactory alternatives, they may still play an integral role in the policy debate. Given the wide disparity in benefits for married couples and same-sex couples, it is unlikely that a ban on same-sex marriage will be supported by the general public without some type of civil union or domestic partnership system accompanying the ban.

\section{Some Preliminary}

\section{Conclusions}

Same-sex marriage is a variation of another wellknown policy issue-legal equality for all-that has been a recurring struggle in this country at least since the Civil War. The issue is sufficiently controversial that Congress and state legislatures will undoubtedly continue to try to pass laws on the subject, as evidenced by the recent general election in 2004. Further, the many court challenges suggest that the Supreme Court may make the final decision.

Although the issue of gay marriage is provocative and certainly not without controversy, the issue may perhaps best be solved not by a one-sided victory but by the implementation of a hybrid model, paying tribute to and drawing ideas from both conservative and liberal sensibilities. Given the long history of marriage in addition to its theological, moral, and ethical aspects, legislators and policy-makers alike may well conclude that marriage, as an institution and a word, is reserved for the union of a man and a woman. However, contemporary society as well as the U.S.'s historical struggle for equal rights suggests that many of the benefits that martied people take for granted-such as the right of survivorship, the right to make medical decisions, and the right to adopt-will one day be extended by these same legislators and policy-makers to same-sex couples.

\section{Notes}

${ }^{1}$ This specific exemption is rooted in two prior U. S. Supreme Court cases that set a precedent of limiting the reach of the Full Faith and Credit clause: 
Nevada v. Hall, 440 U.S. 410 (1979) and Alaska Packers Association u. Industrial Accident Commission of California et al, 294 U.S. 532 (1935).

${ }^{2}$ The states are: Alaska, Atizona, Delaware, Georgia, Idaho, Illinois, Kansas, Michigan, North Carolina, Oklahoma, South Carolina, South Dakota, 'Tennessee, and Utah.

${ }^{3}$ The states are: Alaska, California, Colorado, Connecticut, Delaware, Illinois, Maryland, Massachusetts, Michigan, Minnesota, New Hampshire, New Jersey, New Mexico, New York, Ohio, Oregon, Pennsylvania, Rhode Island, Tennessee, Vermont, Washington and Wisconsin.

${ }^{4}$ The fourteen states with pending constitutional amendments are: Arizona, California, Connecticut, Delaware, Iowa, Illinois, Maine, Minnesota, New Jersey, North Carolina, Oklahoma, South Carolina, Texas, and Washington.

${ }^{5}$ The eleven states passing ballot initiatives are: Arkansas, Georgia, Kentucky, Michigan, Mississippi, Montana, North Dakota, Ohio, Oklahoma, Oregon and Utah.

"The seven states are Connecticut, Maryland, Massachusetts, New Jersey, New Mexico, New York, and Rhode Island.

${ }^{7}$ As the Human Rights Campaign asserts, special categories such as these can be viewed as another example of the "separate and unequal" treatment samesex couples are receiving today (Human Right Campaign 2004).

\section{REFERENCES}

Bennett, Lisa \& Gary J. Gates. 2004. The cost of marriage inequality to gay, lesbian and bisexual seniors. January 29. Washington DC.: A Human Rights Campaign Foundation Report.

Birch. Elizabeth.1996. Congressional testimony before the House Judiciary Committee Subcommittee on the Constitution. May 15. Washington DC: Federal
Information Systems Corporation: Federal News Service.

Clinton, William J. 1996. Statement on same gender marriage. Public Papers of the Presidents. (32 Weekly Comp. Pres. Doc. 1829). September 20.

Congressional Research Service. 1996. Defense of Marriage Act. (96-589 GOV). Mark Eddy, Government Division. December 4.

Congressional Research Service. 2004. Same sex marriages: legal issues. (RL31994). Alison M. Smith, American Law Division. November 4.

Cooperman, Alan. 2004. Same-sex bans fuel conservative agenda. The Wasbington Post. November 4. A39.

Coordination Proceeding, Special Title [Rule 1550 (c)], Marriage Cases. 2005. Superior Court of California, County of San Francisco. Judicial Council Coordination Decision No. 4365, March 14. http://www.sftc.org/Docs/marriage.pdf.

Hartman, Holly. 2004. A primer on same-sex martiage, civil unions, domestic partnerships, and defense of martiage acts. Pearson Education, Infoplease. http://www.infoplease.com/ipa/A0922609.html.

House of Commons of Canada. 2004. An act respecting certain aspects of legal capacity for marriage for civilpurposes. (Bill C-38). http://www.parl.gc.ca/LEGISINFO/ index.asp? Lang $=\mathrm{E} \&$ Chamber $=\mathrm{N} \& S$ tart List $=\mathrm{A} \&$ EndList $=$ Z\&Session $=13 \&$ Type $=0 \&$ Scope $=I \&$ query $=4381 \&$ List $=$ toc -1 .

Human Rights Campaign Web Site. Frequently asked questions about adoption by gay and lesbian parents. Updated March 22, 2004. http://www.hrc.org Template. $f$ in:Section=Adoption\&CONTENTID $=18330 \&$ TEMPLATE = / ContentManagement/ ContentDisplay.cfm.

Human Rights Campaign. 2004. Answers to questions about marriage equality. Washington DC: A Publication of HRC's FamilyNet Project. http://www.hrc.org/ Template.cfm?Section=Get_Involved1\&Template $=$ / ContentManagement / ContentDisplay. cfm\&ContentID $=17262$.

Human Rights Campaign. 2005a. Proposed state constitutional amendments limiting marriage and/or otber forms of relationsbip recognition in 2005-as of March 
17, 2005. Washington D.C. http://www.hrc.org/ Template.cfinPSection=Get_Involved1\&CONTENTID= 25259\&TEMPLATE=/ContentManagement/ ContentDisplay.cfm.

Human Rights Campaign. 2005b. Marriage/relationship laws: State by state. Washington D.C. http:// www.hrc.org/Template.cfm?Section= Center\&CONTENTID=20716\& TEMPLATE $=$ / TaggedPage/TaggedPageDisplay.cfm\&TPLID $=66$.

Jepsen Don. 2005. Bates co-sponsors civil unions bill. The Mail Tribune. April 14. Local Section, Online Edition. http://www.mailtribune.com/archive/ 2005/0414/local/stories/03local.htm.

Kennedy. Senator Edward. 1996. S. 1740: The Defense of Marriage Act. (Congressional Testimony before the Senate Judiciary Committee), July 11. Washington DC: Federal Information Systems Corporation: Federal News Service.

Lexis-Nexis. 1996a. Bill tracking report for the 104th Congress, HR 3396: Defense of Marriage Act. Dayton: LexisNexis. (1996 Bill Tracking H.R. $3396 / 104$ Bill Tracking H.R. 3396). Load Date: December 4, 1996.

Lexis-Nexis. 1996b. Bill tracking report for the 104th Congress, S. 1740: Defense of Marriage Act. Dayton: LexisNexis. (1996 Bill Tracking S. 1740 / 104 Bill Tracking S. 1740). Load Date: December 3, 1996.

Lexis-Nexis. 1996c. Bill tracking report for the 104th Congress, S. 1999: Defense of Marriage Act. Dayton: Lexis-Nexis. (1996 Bill Tracking S. 1999 / 104 Bill Tracking S. 1999). Load Date: September 16, 1996.

Library of Congress. (Thomas). 1996. Bill summary and status for the 104th Congress, H.R 3396. Washington DC: Library of Congress.

Library of Congress (Thomas). 2003a. Bill summary and status for the 108th Congress, H.J.Res 56. Washington DC: Library of Congress.

Library of Congress (Thomas). 2003b. Bill summary and status for the 108th Congress, S.J.Res 26. Washington DC: Library of Congress.

Lott, Senator Trent. 1996. Defense of Marriage Act. Congressional Record. Remarks in the Senate, September 10, 1996, S10100-S10125. (142 Cong $\operatorname{Rec} S 10100$ ).
Medwed, Howard D. 2004. 'Lawrence' has little effect on taxes, for now: The Defense of Marriage Act prevents same-sex couples from enjoying many federal law perks. National Lanu Journal. March 1. 26: $26-15$.

Neustadt, Richard E. 1960. Presidential power and the modern presidents: The politics of leadership from Roosevelt to Reagan. New York: Simon \& Schuster. 29-49. Reprinted in Principles and practices of American politics: Classics and contemporary readings. 2nd ed., edited by Samuel Kernell and Steven S. Smith, 274-294. Washington DC: CQ Press.

Ordonez, Franco. 2004. For gays, adoption irony. The Boston Globe. May 8. B1.

Parliament of Australia. 2004. Marriage legislation amendment bill 2004. (Bills Digest No. 155 2003-04). http://www.aph.gov.au/library/pubs/bd/2003-04/ 04bd155.pdf.

Reference re Same-Sex Marriage. 2004 SCC 79. File No. 29866. Supreme Court of Canada. Decided December 9, 2004.

Rushefsky, Mark E. 2002. Process, structure, and ideology. In Public policy in the United States: at the dawn of the twenty-first century. 3rd ed., 3-52. Armonk: M.E. Sharpe.

Saperstein, Rabbi David. 1996. HR 3396: The Defense of Marriage Act. (Congressional testimony before the House Judiciary Committee Subcommittee on the Constitution), May 15. Washington DC: Federal Information Systems Corporation: Federal News Service.

Sunstein. Cass R. 1996. S. 1740: The Defense of Marriage Act. (Congressional testimony before the Senate Judiciary Committee), July 11. Washington DC: Federal Information Systems Corporation: Federal News Service.

Tom, Representative Terrance W.H. 1996. HR 3396: The Defense of Marriage Act. (Congressional testimony before the House Judiciary Committee Subcommittee on the Constitution), May 15. Washington DC: Federal Information Systems Corporation: Federal News Service.

U.S. Government Accountability Office. 2004. Defense of Marriage Act: Update to prior report. (GAO-04-353R Defense of Marriage Act). January 23. Washington DC: GAO. 
U.S. House. 1996a. Committee on the Judiciary. Defense of Marriage Act: Report together with dissenting views (to accompany H.R. 3396). (H. Rpt. 104-664). Washington DC: GPO.

U.S. House. 1996b. An act to define and protect the institution of marriage: The Defense of Marriage Act. (HR 3396). Washington DC: GPO.

U.S. House. 1996c. Subcommittee on the Constitution. Same-sex marriages (H.R. 3396), May 15. Washington DC: Federal Information Systems Corporation: Federal News Service.

U.S. House 1996d. Subcommittee on the Constitution. Subcommittee markutp of H.R. 3396: The Defense of Marriage Act, May 30. Washington DC: FDCHeMedia, Inc.: Federal Document Clearing House Congressional Testimony.

U.S. House. 1996e. Report on the activities of the Committee on the Judiciary of the House of Representatives during the One Hundred Fourth Congress pursuant to Clause 1(d) Rule XI of the Rules of the House of Representatives. $(\mathrm{H}$. Rpt. 104-879). January 2, 1997. Washington DC: GPO.

U.S. House. 1996f. Committee on the Judiciary. Full committee markup of H.R. 3396: The Defense of Marriage Act, June 11. Washington DC: FDCHeMedia, Inc.: Federal Document Clearing House Congressional Testimony.

U.S. House. 1996g. Roll call vote No. 300 on agreeing to the resolution $\mathrm{H}$. Res. 474 (104th Congress, 2nd Session). Clerk of the House. http:// cletk.house.gov/evs/1996/toll300.xml.

U.S. House $1996 \mathrm{~h}$. Roll call vote No. 314 on agreeing to the Frank of Massachusetts Amendment to H.R. 3396 (104th Congress, 2nd Session). Clerk of the House. http://clerk.house.gov/evs/1996/ roll314.xml.

U.S. House 1996i. Roll call vote No. 316 on passage of the Defense of Marriage Act (104th Congress, 2nd Session). Clerk of the House. http:// clerk.house.gov/evs/1996/roll316.xml.

U.S. Senate. 1996a. Committee on the Judiciary. Same sex marriage, July 11. Washington DC: Congressional Testimony from the Federal Information Systems Corporation: Federal News Service.
U.S. Senate. $1996 \mathrm{~b}$. Roll call vote No. 280 on passage of H.R. 3396 (104th Congress, 2nd Session). Secretary of the Senate. http://www.senate.gov/ legislative/LIS/roll_call_lists/ roll_call_vote_cfin.cfm?congress $=104 \&$ session $=2 \&$ vote $=$ 00280 .

Wardle, Lynn D. 1996. Concerning S. 1740: A more perfect union -- Federalism in American marriage law. (Congressional testimony before the Senate Judiciary Committee), July 11 . Washington DC: Congressional Testimony from FDCHeMedia, Inc.: Federal Document Clearing House Congressional Testimony.

Willing, Richard. 2004. Justices stay out of debate over gays: High court won't rule on same-sex nuptials. USA Today. November 30, A1.

Yardley, William. 2005. Connecticut House backs gay civil unions. The New York Times. April 14. New York/Region. 
